\title{
Microglia and astrocyte responses to neuropathogenic protozoan parasites
}

\author{
Azadeh Nasuhidehnavi ${ }^{1}$ George S. Yap ${ }^{1 *}$ \\ ${ }^{1}$ Center for Immunity and Inflammation, New Jersey Medical School, Rutgers, The State University of New Jersey, Newark, NJ, USA
}

\begin{abstract}
Cerebral toxoplasmosis and cerebral malaria are two important neurological diseases caused by protozoan parasites. In this review, we discuss recent findings regarding the innate immune responses of microglia and astrocytes to Toxoplasma and Plasmodium infection. In both infections, these tissue-resident glial cells perform a sentinel function mediated by alarmin crosstalk that licenses adaptive type 1 immunity in the central nervous system. Divergent protective or pathogenic effects of type 1 activation of these astrocytes and microglia are revealed depending on the inherent lytic potential of the protozoan parasite.
\end{abstract}

\section{Keywords}

Cerebral malaria, cerebral toxoplasmosis, microglia, astrocytes, alarmin, neuroinflammation

\section{Peer Review}

The peer reviewers who approve this article are:

1. Robin Stephens, Department of Internal Medicine, Division of Infectious Diseases, University of Texas Medical Branch, Galveston, TX, USA

Competing interests: No competing interests were disclosed.

2. Alexander W Pfaff, Institut de Parasitologie et Pathologie Tropicale, Fédération de Médecine Translationnelle, Université de Strasbourg, Strasbourg, France

Competing interests: No competing interests were disclosed.

3. Tajie H. Harris, Center for Brain Immunology and Glia, Department of Neuroscience, University of Virginia, Charlottesville, Virginia, USA

Competing interests: No competing interests were disclosed. 
*Corresponding author: George S. Yap (yapgs@njms.rutgers.edu)

Competing interests: The authors declare that they have no competing interests.

Grant information: This work was supported by the grant R21AI129870 from the US National Institute of Health.

The funders had no role in study design, data collection and analysis, decision to publish, or preparation of the manuscript.

Copyright: $\odot 2021$ Yap GS et al. This is an open access article distributed under the terms of the Creative Commons Attribution License, which permits unrestricted use, distribution, and reproduction in any medium, provided the original work is properly cited.

How to cite this article: Nasuhidehnavi A and Yap GS. Microglia and astrocyte responses to neuropathogenic protozoan parasites. Faculty Reviews 2021 10:(69) https://doi.org/10.12703/r/10-69

Published: 03 Sep 2021, Faculty Reviews 10:(69) https://doi.org/10.12703/r/10-69 


\section{Introduction}

Neurological diseases associated with neuroinflammation have an autoimmune, neurodegenerative, or infectious etiology ${ }^{1}$. Although central nervous system (CNS) infections caused by viral and bacterial pathogens have been better studied, neurotropic protozoan parasites also cause two major diseases, namely cerebral toxoplasmosis (CT) and cerebral malaria (CM). CT arises as a result of invasion of the CNS cells by Toxoplasma gondii parasites that exist in both lytic (tachyzoites) and latent (bradyzoites) forms. In immunocompromised patients, life-threatening necrotic encephalitis stems from a failure to control the lytic stage of the parasite. In immunocompetent individuals, $T$. gondii establishes a chronic infection that has been linked to several neuropsychiatric disorders such as anxiety, suicidal behaviors, and schizophrenia ${ }^{2-4}$. Unlike in CT, there is no threat of parasite replication in neural cells in $\mathrm{CM}$, and neuropathological symptoms occur acutely. It is thought that occlusion of cerebral microvasculature by Plasmodium-infected red blood cells (iRBCs) causes increased blood-brain barrier (BBB) permeability, hemorrhage, and induction of cerebral hypoxia ${ }^{5}$. In a mouse model of experimental CM (ECM), inflammation caused by sequestered inflammatory leukocytes, including monocytes and $\mathrm{CD}^{+} \mathrm{T}$ cells, also contributed to the development of secondary neurological symptoms ${ }^{6,7}$. CM often appears as a severe and lethal neurological complication, but even after recovery, long-term neurological deficits such as cognitive and behavioral disorders persist in children with complicated malaria ${ }^{8}$.

Here, we discuss the most recent findings regarding the immune responses of two major CNS glial cells-microglia and astrocytes-during Toxoplasma and Plasmodium infection. In both $\mathrm{CT}$ and $\mathrm{CM}$, microglia and astrocytes mount a shared $\mathrm{T}$ helper $1\left(\mathrm{~T}_{\mathrm{H}} 1\right)$ program of pro-inflammatory and anti-inflammatory cytokine cascades that have divergent protective and pathogenic effects largely dictated by the inherent lytic threat posed by the pathogen to the tissue integrity of the CNS. The mechanistic studies discussed in this short review largely use established mouse models to $\mathrm{CT}$ and $\mathrm{CM}$ that recapitulate key pathogenetic and clinical features of their respective human diseases.

\section{Microglia responses in cerebral toxoplasmosis and cerebral malaria}

Microglia are CNS-resident immune cells originating from yolk sac myeloid progenitors with multifaceted functions during physiological and pathological conditions ${ }^{9}$ Microglia constantly monitor their microenvironment and respond to pathogenic infections exhibiting reactive phenotypes and immune responses $^{10}$. Moreover, engagement of microglia and astrocytes in the neurovascular unit allows the initiation of glial effector functions in response to BBB injury ${ }^{11}$. Several lines of evidence demonstrated microglia activation during Toxoplasma and Plasmodium infection. In vitro studies showed that upon exposure to $T$. gondii tachyzoites and Plasmodium-iRBCs, microglia underwent morphological changes and upregulated the expression of inflammatory markers ${ }^{12,13}$. An important question is whether the microglial phenotype is modulated through direct effects of the parasites or exposure to inflammatory mediators. Bhandage et al. revealed that T. gondii-infected microglia displayed a hypermotile phenotype dependent on the presence of live parasites in the cells ${ }^{14}$. Microglial hypermigratory behavior is mediated by autocrine GABAergic signaling in $T$. gondii-infected cells ${ }^{14}$. However, these data were derived from in vitro studies, and the behavior of infected microglia in vivo needs to be investigated.

In contrast to $T$. gondii infection, Plasmodium-iRBCs do not directly interact with microglia. Instead, hemodynamic alterations resulting from adherence of inflammatory leukocytes to postcapillary venule endothelium lead to leakage of plasma into the postcapillary space $^{15}$. Exposure of microglia to inflammatory milieu in the postcapillary space may lead to their activation ${ }^{15}$. In addition, oxygen deprivation may provide additional cues for microglial activation ${ }^{16}$. Collectively, microglial activation can stem from direct interaction with the parasites or changes in the microenvironment surrounding the tissue harboring parasitic lesions.

A hallmark of microglial activation is their acquisition of a pro-inflammatory phenotype. The interleukin 1 (IL-1) family is one of the important groups of pro-inflammatory cytokines upregulated in reactive microglia during several neurodegenerative diseases ${ }^{17,18}$. The role of microglial IL-1 expression has been investigated in $\mathrm{CT}$ and $\mathrm{CM}$. A recent study from the Harris lab indicates that IL- $1 \alpha$ signaling is critical for the interplay between CNS cells during $\mathrm{CT}^{19}$. Using RNA sequencing, transgenic mice, and ex vivo cytokine assays, the authors showed that microglia was the major source of $\mathrm{IL}-1 \alpha$ in $T$. gondii-infected brain ${ }^{19}$. Moreover, IL- $1 \alpha$ plays a critical role in the recruitment of immune cells and consequently restriction of parasite growth. The protective effect of microglial IL- $1 \alpha$ is mediated by upregulating expression of adhesion molecules on endothelial cells ${ }^{19}$.

Though clearly protective in CT, microglial IL-1 has potential adverse effects on neuronal function in ECM. Reverchon et al. showed that induction of microglial IL-1 $\beta$ during ECM was associated with impairment of memory and learning ${ }^{20,21}$. Interestingly, this microglial IL-1 response appears to be driven by IL-33 produced by astrocytes and oligodendrocytes ${ }^{20,21}$. IL-1 itself enhanced IL-33 production by oligodendrocytes, suggesting a potent synergistic crosstalk between microglia and oligodendrocytes mediated by alarmins that may augment the neuroinflammatory responses and neurological symptoms during ECM. Although these results suggest that the reduction of endogenous IL-33 may be a therapeutic target for ECM and alleviates neuronal damage, other studies show that exogenous administration of IL-33 in the early stages of ECM has protective outcomes. IL-33 treatment with or without coadministration of antimalaria drugs results in a reduction of cerebral lesions and amelioration of 
neuropathological symptoms ${ }^{22,23}$. The protective effects of exogenous IL-33 were associated with $\mathrm{T}_{\mathrm{H}} 2$ cell polarization, regulatory T-cell response and decreased inflammasome activation in microglia, and most likely a reduction in destructive $\mathrm{T}_{\mathrm{H}} 1$ response $\mathrm{r}^{22,23}$.

Tumor necrosis factor alpha (TNF- $\alpha$ ) is another major pro-inflammatory cytokine contributing to the development of $\mathrm{CT}$ and $\mathrm{CM}$ pathogenesis. In CT, TNF- $\alpha$ signaling has a protective role as it is crucial for microglial production of nitric oxide and restriction of parasite growth ${ }^{24,25}$. Conversely in ECM, it appears that TNF- $\alpha$ signaling is detrimental as it mediates intercellular adhesion molecule 1 (ICAM-1) upregulation in brain endothelial cells and leukocyte sequestration ${ }^{26}$. In vitro studies showed that TNF- $\alpha$ was upregulated in microglia during $T$. gondii infection and Plasmodium-derived extracellular vesicle/iRBC stimulation ${ }^{13,27,28}$. In addition, microglial TNF- $\alpha$ level is increased in T. gondii- and $P$. berghei ANKA (PbA)-infected mice ${ }^{29,30}$. Deckert-Schlüter et al. reported that TNF- $\alpha$ induction in microglia during CT was dependent on signals downstream of the interferon gamma (IFN- $\gamma$ ) receptor $^{31}$. Depletion of $\mathrm{CD}^{+} \mathrm{T}$ cells, a major source of IFN- $\gamma$, results in impaired production of microglial cytokines, including TNF- $\alpha$ in $T$. gondii-infected brain, highlighting a regulatory role for $\mathrm{T}$ cells and IFN- $\gamma$ signaling on microglia cytokine production ${ }^{32}$. Furthermore, production of IFN- $\gamma$ by microglia themselves ${ }^{33}$ may serve as an autocrine signal for TNF- $\alpha$ production.

Given the potent effects of TNF- $\alpha$ on CNS physiology, such as the regulation of synaptic activity ${ }^{34}$, and CNS remyelination ${ }^{35}$, it will be important to interrogate the effects of increased levels of TNF- $\alpha$ on neuronal and astroglia functions during CT and CM. For example, impairment of neurotransmitter uptake occurs in TNF- $\alpha$-activated astrocytes ${ }^{36}$ and may result in excessive neuronal excitatory stimulation and death. Moreover, neutralization of TNF- $\alpha$ in IL-10-deficient mice infected with Plasmodium chabaudi reduces astrocyte activation and disease severity ${ }^{37}$.

The phagocytic function of microglia represents an important aspect of the intimate microglia-neuron interaction, as it is crucial for elimination of undesired synapses and apoptotic neurons $^{38}$. A recent study by Carrillo et al. showed that chronic CT caused the loss of perisomatic inhibitory synapses and ensheathment of neurons by activated microglia in hippocampus and neocortex ${ }^{39}$. Li et al. further advanced our understanding about molecular mechanisms underlying microglia-neuron interaction during $\mathrm{CT}^{40}$. The authors reported that degenerating neurons marked by complement proteins (C1q and C3) and elevated levels of fractalkine chemokine (CX3CL1) were surrounded by activated microglia. As the fractalkine receptor (CX3CR1), among CNS cells, is exclusively expressed on microglia $\mathrm{a}^{41}$, fractalkine signaling may regulate the recruitment of microglia to the site of tissue injury and initiate microglia-neuron communication during CT. Furthermore, the presence of complement protein deposits on damaged neurons makes them susceptible to clearance by surrounding microglia ${ }^{40}$. Collectively, these findings suggest that destruction of inhibitory synapse and neuronal structures by phagocytic microglia may cause neuronal dysfunction leading to the emergence of neurological problems.

\section{Astrocyte responses in cerebral toxoplasmosis and cerebral malaria}

Astrocytes, the most abundant glial cell type in the CNS, constitute a heterogenous cell population that maintains neuronal homeostasis. Astrocytes perform a plethora of functions, including regulation of energy metabolism ${ }^{42}$, supporting synaptic structure and plasticity ${ }^{43,44}$, and maintenance and regulation of the $\mathrm{BBB}^{45}$.

Disruption of the BBB integrity is a critical step in the pathogenesis of $\mathrm{CM}$ leading to brain edema that damages neuronal structure $^{46}$. Medana et al. reported that retinal astrocytes exhibited an uneven distribution and ensheathment of retinal blood vessels before the expression of neurological signs ${ }^{47}$. Furthermore, in the late stages of ECM, retinal astrocytes lost their contact with the blood-retinal barrier $(\mathrm{BRB})^{47}$. These findings suggest that loss of astrocytic support on BRB may be involved in the BRB compromise, hemorrhage, and edema.

Astrocytes respond to noxious insults through rapid morphological changes that contain and restrict the spread of tissue injury. Upregulation of the astrocytic cytoskeletal glial fibrillary acidic protein (GFAP) and the subsequent reactive astrogliosis limit pathogen distribution in the $\mathrm{CNS}^{48}$. Activated astrocytes with increased GFAP levels have been observed in the brain during chronic $\mathrm{CT}^{49}$ and $\mathrm{ECM}^{13}$. The protective role of GFAP upregulation during CT was demonstrated by Stenzel et $a l^{49}$. The authors showed that GFAP knockout (KO) mice infected with $T$. gondii were unable to control parasite growth and confine inflammatory lesions caused by the parasite ${ }^{49}$. These findings emphasize that activation of astrocytes is critical for a strong protective anti-Toxoplasma response. It is not yet clear whether GFAP upregulation is associated with protective or detrimental outcomes in CM. Mice lacking both astrocytic intermediate filaments-GFAP and vimentin-have been shown to exhibit impaired astrocyte activation and larger infarct size after ischemic brain injury ${ }^{50}$. Given the presence of sequestered iRBCs, occlusion of the $\mathrm{BBB}$, and induction of hypoxia described in ECM, it is critical to investigate the role of astrocyte reactivity in this disease.

Astrocytes also mount diverse immunological responses, including production of specific pro- and anti-inflammatory mediators during CT and ECM. IFN- $\gamma$ plays a critical role in the destruction of $T$. gondii in the host cells through different mechanisms ${ }^{51}$. One of the mechanisms is the activation of signal transducer STAT1, which induces transcription of IFN- $\gamma$-dependent genes such as IRF-152. Using transgenic mice with specific deletion of STAT1 in astrocytes, 
Hidano et al. showed that a more severe form of CT developed with a higher mortality and cerebral parasite load, suggesting that the astrocytic IFN- $\gamma$ signaling response to the parasite has protective outcomes ${ }^{53}$. Moreover, loss of STAT1 signaling in astrocytes caused a shift in parasite tropism from neurons to astrocytes as higher numbers of parasite cysts appeared in STAT1 KO astrocytes ${ }^{53}$. The protective function of astrocytes in response to IFN- $\gamma$ and clearance of parasites could be one explanation of why there are no $T$. gondii astrocytic cysts in wild-type (WT) mice. IFN- $\gamma$ production during $\mathrm{ECM}$, in contrast to $\mathrm{CT}$, contributes to cerebral increase of Plasmodium biomass since IFN- $\gamma$-deficient mice exhibit lower parasite loads and iRBCs in the brain ${ }^{54}$. Of note, IFN- $\gamma$ produced by $\mathrm{CD}^{+} \mathrm{T}$ cells induces expression of CXCL9 and CXCL10 in cerebral endothelial cells, leading to firm attachment of $\mathrm{T}$ cells to brain vasculature and ultimately infiltration of cytotoxic $\mathrm{CD}^{+} \mathrm{T}$ cells ${ }^{55-57}$. Although the sources of CXCL9 and CXCL10 during ECM have not been completely determined, astrocytes may represent a potential source for these chemokines as PbA-iRBC-stimulated astrocytes displayed increased levels of CXCL10 ${ }^{13}$.

The signaling pathway downstream of glycoprotein 130 (gp130), the ubiquitous signal transducer for members of the IL-6 cytokine family, plays a critical role in the establishment of protective and detrimental responses during CT and ECM. IL-6 signaling regulates various functions in astrocytes, such as activation of JAK/STAT3 signaling pathway, regulation of cell proliferation, and expression of GFAP and vimentin ${ }^{58,59}$. It has been demonstrated that IL-6 is required for the restriction of $T$. gondii proliferation in the brain and the development of protective response against $\mathrm{CT}^{60}$. In vivo deletion of astrocytic gp130 resulted in reduced astrocyte activation leading to impaired parasite confinement and ultimately the development of extensive necrotic lesions ${ }^{61}$. Conversely, in ECM, IL-6 production has been associated with neurotoxic sequelae. Administration of anti-IL-6 neutralizing antibodies in $\mathrm{PbA}$-infected mice resulted in reduced astrocyte activation associated with decreased glial nodules, neuronal death, and longer survival ${ }^{62}$, suggesting neurotoxic roles of astrocytes driven by IL-6 signaling in ECM.

IL-33 is released from necrotic cells as a cellular alarmin and interacts with its receptor, the orphan IL-1 receptor family member ST2. It has been demonstrated that ST2 is upregulated during $\mathrm{CT}$ in the brain, and IL-33/ST2 signaling is found to prevent $T$. gondii growth and decrease neural tissue destruction ${ }^{63}$. Still et al. showed that oligodendrocytes and astrocytes were the major sources of IL-33 in $T$. gondii-infected brain ${ }^{64}$. Importantly, IL-33 signals on astrocytes through ST2 receptor leading to the production of inflammatory chemokines such as CCL2 and CXCL10 and infiltration of leukocytes which results in the control of infection ${ }^{64}$. As discussed above, astrocytes in addition to oligodendrocytes also produce IL-33 during $\mathrm{ECM}^{20}$. In turn, IL-33 production by astrocytes likely leads to enhanced synaptic engulfment by microglia ${ }^{65}$ and increases the formation of excitatory synapses by neurons ${ }^{66}$. Therefore, it will be important to know how synapse structure and neuronal function are dysregulated by IL-33 produced during both CT and ECM, even though IL-33 has a clear protective effect by controlling Toxoplasma infection in the brain.

Transforming growth factor beta 1 (TGF- $\beta 1$ ) is a pleiotropic cytokine that negatively regulates immunopathological responses during neuroinflammatory disorders. Cekanaviciute et al. reported that TGF- $\beta 1$ signaling with anti-inflammatory effects was induced in astrocytes in response to $T$. gondii infection ${ }^{67}$. That study showed that in vivo inhibition of astrocytic TGF- $\beta 1$ signaling did not affect $T$. gondii burden in the brain but did result in increased activation of nuclear factor kappa B (NF- $\mathrm{KB})$ pathway and subsequently upregulation of CCL5, accompanied by increased T-cell infiltration and neuronal death ${ }^{67}$. NF- $\kappa \mathrm{B}$ activation in astrocytes regulates inflammatory responses involved in pathological outcomes of neurodegenerative diseases (reviewed in 68). For example, activation of astroglia NF- $\mathrm{KB}$ leads to overexpression of complement protein $\mathrm{C} 3$, reduced synaptogenesis, and disruption of dendrite morphology contributing to impairment of neuronal activity ${ }^{69}$. In vitro inhibition of $\mathrm{NF}-\kappa \mathrm{B}$ in astrocytes exposed to $T$. gondii antigens consistently decreased the levels of neurotoxic markers, including complement protein $\mathrm{C} 3$, suggesting that astrocytic $\mathrm{NF}-\mathrm{\kappa B}$ signaling may contribute to neurological deficits of $\mathrm{CT}^{70}$. However, by inducing IL-1, NF- $\kappa B$ signaling itself is critical for instigating TGF- $\beta$ counter-regulation ${ }^{71}$. Negative feedback regulation by TGF- $\beta$ may represent an important mechanism for minimizing the detrimental effects of the pro-inflammatory response while maintaining its parasite restrictive functions.

In addition to mediating immunoregulatory TGF- $\beta$ signaling, astrocytes perform neuroprotective functions, including maintenance of brain water homeostasis and antioxidant defense. Expression of the water channel aquaporin-4 (AQP4) by astrocytes is critical for preventing excessive brain edema during $\mathrm{ECM}^{72,73}$. Upregulation of the antioxidant protein neuroglobin by astrocytes during $\mathrm{ECM}^{74}$ may also minimize tissue injury.

\section{Concluding remarks}

Here, we have discussed the experimental evidence indicating that microglia and astrocytes are critical regulators of CNS immune responses during Toxoplasma and Plasmodium infection. Reflecting the distinct cellular tropisms of these two infections, these immune responses are primarily protective in CT because they drive effector mechanisms critical for controlling T. gondii replication in the CNS. By contrast, in $\mathrm{CM}$, the $\mathrm{T}_{\mathrm{H}} 1$ response is largely detrimental, negatively affecting neurological function. However, it is likely that collateral neurotoxic effects occur during CT when the extent of glial activation exceeds what is required for parasite removal. As shown in Figure 1, tissue-resident astrocytes and microglia act as sentinel innate cells that trigger the infiltration/sequestration of the CNS by the peripheral immune 


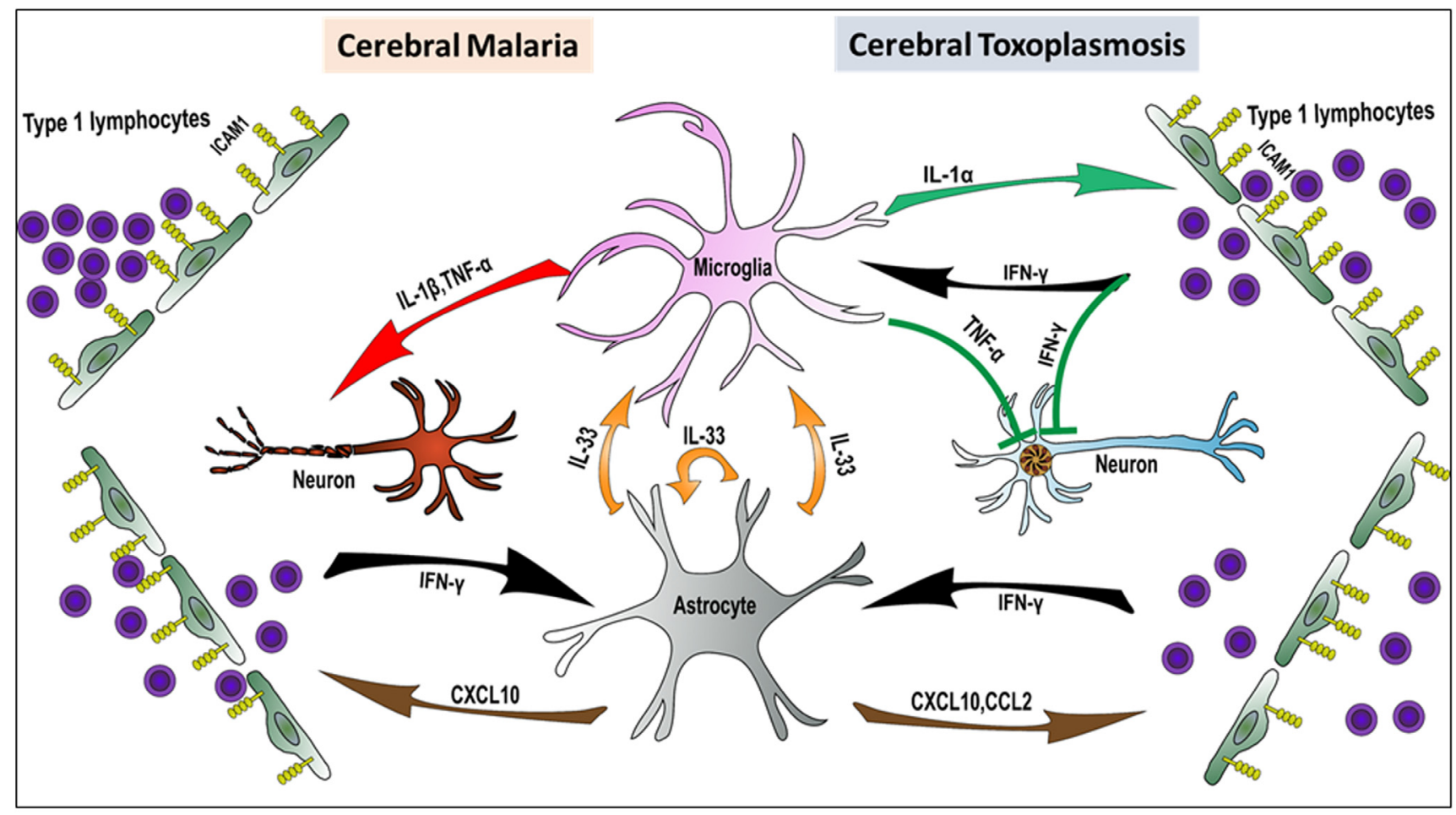

Figure 1. Alarmin-mediated microglia-astrocyte crosstalk during cerebral toxoplasmosis (right) and cerebral malaria (left). Activated astrocytes and microglia initiate signaling pathways required for peripheral immune cell infiltration/sequestration. In cerebral toxoplasmosis, these immune pathways result in the control of Toxoplasma gondii replication and partial restoration of tissue homeostasis. Conversely, in cerebral malaria, immune responses elicited in microglia and astrocytes lead to impairment of neuronal function and exacerbation of neurological symptoms. ICAM1, intercellular adhesion molecule 1; IFN- $\gamma$, interferon gamma; IL, interleukin; TNF- $\alpha$, tumor necrosis factor alpha.

cells. Crosstalk between astrocytes (also oligodendrocytes) and microglia is mediated by the alarmins IL-33 and IL-1. It will be important to investigate what parasite-derived versus endogenous signals drive alarmin upregulation and release.

The primary consequence of immune infiltration by type 1 lymphocytes is the differentiation of microglia and astrocytes into M1-like and A1-like type cells ${ }^{75,76}$, that have antiparasitic effector functions but also possess neurotoxic potential. As discussed above, immunoregulation by TGF- $\beta$ is essential for curtailing this inherently destructive potential. What signals trigger the transitioning of astrocyte and microglial phenotypes from neurotoxic to reparative is another area for future studies. Deployment of single-cell RNA-sequencing technology will be helpful in defining the cellular heterogeneity, dynamics, and regulatory circuits that govern this important transition.
1. Amor S, Puentes F, Baker D, et al: Inflammation in neurodegenerative diseases. Immunology. 2010; 129(2): 154-69.

PubMed Abstract | Publisher Full Text | Free Full Text

2. Arling TA, Yolken RH, Lapidus M, et al:: Toxoplasma gondii antibody titers and history of suicide attempts in patients with recurrent mood disorders. $J$ Nerv Ment Dis. 2009; 197(12): 905-8.

PubMed Abstract | Publisher Full Text

3. Torrey EF, Yolken RH: Toxoplasma gondii and schizophrenia. Emerging
Infect Dis. 2003; 9(11): 1375-80.

PubMed Abstract | Publisher Full Text | Free Full Text |

Faculty Opinions Recommendation

4. Flegr J, Horáček J: Negative Effects of Latent Toxoplasmosis on Mental Health. Front Psychiatry. 2019; 10: 1012.

PubMed Abstract | Publisher Full Text | Free Full Text

5. Hunt NH, Ball HJ, Hansen AM, et al.: Cerebral malaria: Gamma-interferon redux. Front Cell Infect Microbiol. 2014; 4: 113.

PubMed Abstract | Publisher Full Text | Free Full Text 
6. Hearn J, Rayment N, Landon DN, et al.: Immunopathology of cerebral malaria: Morphological evidence of parasite sequestration in murine brain microvasculature. Infect Immun. 2000; 68(9): 5364-76. PubMed Abstract | Publisher Full Text | Free Full Text

7. Belnoue E, Kayibanda M, Vigario AM, et al:: On the pathogenic role of brain-sequestered alphabeta CD8+ T cells in experimental cerebral malaria. J Immunol. 2002; 169(11): 6369-75.

PubMed Abstract | Publisher Full Text

8. Idro R, Marsh K, John CC, et al:: Cerebral malaria: Mechanisms of brain injury and strategies for improved neurocognitive outcome. Pediatr Res. 2010; 68(4): 267-74

PubMed Abstract | Publisher Full Text | Free Full Text

9. Li Q, Barres BA: Microglia and macrophages in brain homeostasis and disease. Nat Rev Immunol. 2018; 18(4): 225-42.

PubMed Abstract | Publisher Full Text

10. Crotti A, Ransohoff RM: Microglial Physiology and Pathophysiology: Insights from Genome-wide Transcriptional Profiling. Immunity. 2016; 44(3): 505-15. PubMed Abstract | Publisher Full Text

11. Liu LR, Liu JC, Bao JS, et al:: Interaction of Microglia and Astrocytes in the Neurovascular Unit. Front Immunol. 2020; 11: 1024. PubMed Abstract | Publisher Full Text | Free Full Text

12. Dellacasa-Lindberg I, Fuks JM, Arrighi RBG, et al.: Migratory activation of primary cortical microglia upon infection with Toxoplasma gondii. Infect Immun. 2011; 79(8): 3046-52.

PubMed Abstract | Publisher Full Text | Free Full Text

13. Shrivastava SK, Dalko E, Delcroix-Genete D, et al:: Uptake of parasite-derived vesicles by astrocytes and microglial phagocytosis of infected erythrocytes may drive neuroinflammation in cerebral malaria. Glia. 2017; 65(1): 75-92. PubMed Abstract | Publisher Full Text

14. Bhandage AK, Kanatani S, Barragan A: Toxoplasma- Induced Hypermigration of Primary Cortical Microglia Implicates GABAergic Signaling. Front Cell Infect Microbiol. 2019; 9: 73

PubMed Abstract | Publisher Full Text | Free Full Text | Faculty Opinions Recommendation

15. Nacer A, Movila A, Sohet $F$, et al:: Experimental cerebral malaria pathogenesis--hemodynamics at the blood brain barrier. PLOS Pathog. 2014; 10(12): e1004528.

PubMed Abstract | Publisher Full Text | Free Full Text

16. Kaur C, Rathnasamy G, Ling EA: Roles of activated microglia in hypoxia induced neuroinflammation in the developing brain and the retina. J Neuroimmune Pharmacol. 2013; 8(1): 66-78. PubMed Abstract | Publisher Full Text

17. Wang WY, Tan MS, Yu JT, et al.: Role of pro-inflammatory cytokines released from microglia in Alzheimer's disease. Ann Transl Med. 2015; 3(10): 136. PubMed Abstract | Publisher Full Text | Free Full Text

18. Hickman S, Izzy S, Sen $\mathrm{P}$, et al:: Microglia in neurodegeneration. Nat Neurosci. 2018; 21(10): 1359-69.

PubMed Abstract | Publisher Full Text | Free Full Text

19. C Batista SJ, Still KM, Johanson D, et al:: Gasdermin-D-dependent IL-10 release from microglia promotes protective immunity during chronic Toxoplasma gondii infection. Nat Commun. 2020; 11(1): 3687. PubMed Abstract | Publisher Full Text | Free Full Text | Faculty Opinions Recommendation

20. Reverchon F, Mortaud S, Sivoyon M, et al.: IL-33 receptor ST2 regulates the cognitive impairments associated with experimental cerebral malaria. PLoS Pathog. 2017; 13(4): e1006322.

PubMed Abstract | Publisher Full Text | Free Full Text

21. Reverchon F, de Concini V, Larrigaldie V, et al:: Hippocampal interleukin-33 mediates neuroinflammation-induced cognitive impairments. $J$ Neuroinflammation. 2020; 17(1): 268. PubMed Abstract | Publisher Full Text | Free Full Text

22. Besnard AG, Guabiraba R, Niedbala W, et al.: IL-33-mediated protection against experimental cerebral malaria is linked to induction of type 2 innate lymphoid cells, M2 macrophages and regulatory T cells. PLOS Pathog. 2015; 11(2): e1004607.

PubMed Abstract | Publisher Full Text | Free Full Text

23. Strangward $\mathrm{P}$, Haley MJ, Albornoz MG, et al:: Targeting the IL33-NLRP3 axis improves therapy for experimental cerebral malaria. Proc Natl Acad Sci U S A. 2018; 115(28): 7404-9.

PubMed Abstract | Publisher Full Text | Free Full Text

24. Deckert-Schlüter $\mathrm{M}$, Bluethmann $\mathrm{H}$, Rang $\mathrm{A}$, et al.: Crucial role of TNF receptor type 1 (p55), but not of TNF receptor type 2 (p75), in murine toxoplasmosis. $J$ Immunol. 1998; 160(7): 3427-36.

PubMed Abstract

25. Gazzinelli RT, Eltoum I, Wynn TA, et al:: Acute cerebral toxoplasmosis is induced by in vivo neutralization of TNF-alpha and correlates with the downregulated expression of inducible nitric oxide synthase and other markers of macrophage activation. J Immunol. 1993; 151(7): 3672-81. PubMed Abstract

26. Lucas R, Lou JN, Juillard $P$, et al.: Respective role of TNF receptors in the development of experimental cerebral malaria. J Neuroimmunol. 1997; 72(2): 143-8.

PubMed Abstract | Publisher Full Text
27. Mbagwu SI, Lannes N, Walch M, et al:: Human Microglia Respond to Malaria-Induced Extracellular Vesicles. Pathogens. 2019; 9(1): 21. PubMed Abstract | Publisher Full Text | Free Full Text

28. Fischer HG, Nitzgen B, Reichmann G, et al.: Cytokine responses induced by Toxoplasma gondii in astrocytes and microglial cells. Eur J Immunol. 1997; 27(6): 1539-48.

PubMed Abstract | Publisher Full Text

29. Medana IM, Hunt NH, Chaudhri G: Tumor necrosis factor-alpha expression in the brain during fatal murine cerebral malaria: Evidence for production by microglia and astrocytes. Am J Pathol. 1997; 150(4): 1473-86.

PubMed Abstract | Free Full Text

30. Deckert M, Sedgwick JD, Fischer E, et al:: Regulation of microglial cell responses in murine Toxoplasma encephalitis by CD200/CD200 receptor interaction. Acta Neuropathol. 2006; 111(6): 548-58.

PubMed Abstract | Publisher Full Text

31. Deckert-Schlüter M, Bluethmann $\mathrm{H}$, Kaefer N, et al.: Interferon-gamma Receptor-Mediated but Not Tumor Necrosis Factor Receptor Type 1- or Type 2-Mediated Signaling Is Crucial for the Activation of Cerebral Blood Vesse Endothelial Cells and Microglia in Murine Toxoplasma Encephalitis. Am J Pathol. 1999; 154(5): 1549-61.

PubMed Abstract | Publisher Full Text | Free Full Text

32. Schlüter D, Meyer T, Strack A, et al:: Regulation of microglia by $\mathrm{CD}^{+}$and $\mathrm{CD}^{+} \mathrm{T}$ cells: Selective analysis in CD45-congenic normal and Toxoplasma gondii-infected bone marrow chimeras. Brain Pathol. 2001; 11(1): 44-55. PubMed Abstract | Publisher Full Text

33. Suzuki Y, Claflin J, Wang X, et al:: Microglia and macrophages as innate producers of interferon-gamma in the brain following infection with Toxoplasma gondii. Int J Parasitol. 2005; 35(1): 83-90.

PubMed Abstract | Publisher Full Text

34. Rizzo FR, Musella A, de Vito F, et al.: Tumor Necrosis Factor and Interleukin-1 $\beta$ Modulate Synaptic Plasticity during Neuroinflammation. Neural Plast. 2018; 2018: 8430123 .

PubMed Abstract | Publisher Full Text | Free Full Text

35. Arnett HA, Mason J, Marino M, et al.: TNF alpha promotes proliferation of oligodendrocyte progenitors and remyelination. Nat Neurosci. 2001; 4(11): 1116-22.

PubMed Abstract | Publisher Full Text

36. Trindade P, Loiola EC, Gasparotto J, et al:: Short and long TNF-alpha exposure recapitulates canonical astrogliosis events in human-induced pluripotent stem cells-derived astrocytes. Glia. 2020; 68(7): 1396-409. PubMed Abstract | Publisher Full Text

37. Wilson KD, Ochoa LF, Solomon OD, et al: : Elimination of intravascular thrombi prevents early mortality and reduces gliosis in hyper-inflammatory experimental cerebral malaria. J Neuroinflammation. 2018; 15(1): 173. PubMed Abstract | Publisher Full Text | Free Full Text

38. Galloway DA, Phillips AEM, Owen DRJ, et al:: Phagocytosis in the Brain: Homeostasis and Disease. Front Immunol. 2019; 10: 790. PubMed Abstract | Publisher Full Text | Free Full Text

39. Carrillo GL, Ballard VA, Glausen T, et al.: Toxoplasma infection induces microglia-neuron contact and the loss of perisomatic inhibitory synapses. Glia. 2020; 68(10): 1968-86.

PubMed Abstract | Publisher Full Text | Free Full Text Faculty Opinions Recommendation

40. Li Y, Severance EG, Viscidi RP, et al.: Persistent Toxoplasma Infection of the Brain Induced Neurodegeneration Associated with Activation of Complement and Microglia. Infect Immun. 2019; 87(8): e00139-19. PubMed Abstract | Publisher Full Text | Free Full Text | Fubulty Opinions Recommendation

41. Cardona AE, Pioro EP, Sasse ME, et al:: Control of microglial neurotoxicity by the fractalkine receptor. Nat Neurosci. 2006; 9(7): 917-24. PubMed Abstract | Publisher Full Text | Faculty Opinions Recommendation

42. Morita M, Ikeshima-Kataoka $\mathrm{H}$, Kreft M, et al:: Metabolic Plasticity of Astrocytes and Aging of the Brain. Int J Mol Sci. 2019; 20(4): 941. PubMed Abstract | Publisher Full Text | Free Full Text

43. Allen NJ, Eroglu C: Cell Biology of Astrocyte-Synapse Interactions. Neuron. 2017; 96(3): 697-708.

PubMed Abstract | Publisher Full Text | Free Full Text | Faculty Opinions Recommendation

44. Perez-Catalan NA, Doe CQ, Ackerman SD: The role of astrocyte-mediated plasticity in neural circuit development and function. Neural Dev. 2021; 16(1): 1 .

PubMed Abstract | Publisher Full Text | Free Full Text

45. Daneman R, Prat A: The blood-brain barrier. Cold Spring Harb Perspect Biol. 2015; 7(1): a020412.

PubMed Abstract | Publisher Full Text | Free Full Text

46. Tunon-Ortiz A, Lamb TJ: Blood brain barrier disruption in cerebral malaria: Beyond endothelial cell activation. PLoS Pathog. 2019; 15(6): e1007786. PubMed Abstract | Publisher Full Text | Free Full Text

47. Medana IM, Chan-Ling T, Hunt NH: Redistribution and degeneration of retinal astrocytes in experimental murine cerebral malaria: Relationship to disruption of the blood-retinal barrier. Glia. 1996; 16(1): 51-64.

PubMed Abstract | Publisher Full Text 
48. Sofroniew MV: Molecular dissection of reactive astrogliosis and glial scar formation. Trends Neurosci. 2009; 32(12): 638-47. PubMed Abstract | Publisher Full Text | Free Full Text

49. Stenzel W, Soltek $\mathrm{S}$, Schlüter $\mathrm{D}$, et al:: The intermediate filament GFAP is important for the control of experimental murine Staphylococcus aureus-induced brain abscess and Toxoplasma encephalitis. J Neuropathol Exp Neurol. 2004; 63(6): 631-40. PubMed Abstract | Publisher Full Text

50. Li L, Lundkvist A, Andersson D, et al.: Protective role of reactive astrocytes in brain ischemia. J Cereb Blood Flow Metab. 2008; 28(3): 468-81. PubMed Abstract | Publisher Full Text

51. Könen-Waisman S, Howard JC: Cell-autonomous immunity to Toxoplasma gondii in mouse and man. Microbes Infect. 2007; 9(14-15): 1652-61. PubMed Abstract | Publisher Full Text

52. Krause $\mathrm{CD}, \mathrm{He} \mathrm{W}$, Kotenko $\mathrm{S}$, et al:: Modulation of the activation of Stat1 by the interferon-gamma receptor complex. Cell Res. 2006; 16(1): 113-23. PubMed Abstract | Publisher Full Text

53. Hidano S, Randall LM, Dawson L, et al:: STAT1 Signaling in Astrocytes Is Essential for Control of Infection in the Central Nervous System. mBio. 2016; 7(6): e01881-16.

PubMed Abstract | Publisher Full Text | Free Full Text

54. Claser C, Malleret B, Gun SY, et al:: $\mathrm{CD8}^{+} \mathrm{T}$ cells and IFN- $\gamma$ mediate the time-dependent accumulation of infected red blood cells in deep organs during experimental cerebral malaria. PLOS One. 2011; 6(4): e18720. PubMed Abstract | Publisher Full Text | Free Full Text

55. Villegas-Mendez A, Greig R, Shaw TN, et al:: IFN- $\gamma$-producing $\mathrm{CD4}^{+} \mathbf{T}$ cells promote experimental cerebral malaria by modulating $\mathrm{CD}^{+} \mathrm{T}$ cell accumulation within the brain. $J$ Immunol. 2012; 189(2): 968-79. PubMed Abstract | Publisher Full Text | Free Full Text

56. Sorensen EW, Lian J, Ozga AJ, et al:: CXCL10 stabilizes T cell-brain endothelia cell adhesion leading to the induction of cerebral malaria. JCl Insight. 2018; 3(8): e98911

PubMed Abstract | Publisher Full Text | Free Full Text

57. Ghazanfari N, Gregory JL, Devi S, et al: $\mathrm{CD}^{+}$and $\mathrm{CD4} 4^{+} \mathrm{T}$ Cells Infiltrate into the Brain during Plasmodium berghei ANKA Infection and Form Long-Term Resident Memory. J Immunol. 2021; ji2000773. PubMed Abstract | Publisher Full Text

58. Selmaj KW, Faroog M, Norton WT, et al:: Proliferation of astrocytes in vitro in response to cytokines. A primary role for tumor necrosis factor. $J$ Immunol. 1990; 144(1): 129-35. PubMed Abstract

59. Ben Haim L, Carrillo-de Sauvage MA, Ceyzériat $\mathrm{K}$, et al: Elusive roles for reactive astrocytes in neurodegenerative diseases. Front Cell Neurosci. 2015; 9: 278. PubMed Abstract | Publisher Full Text | Free Full Text

60. Suzuki Y, Rani S, Liesenfeld O, et al.: Impaired resistance to the development of toxoplasmic encephalitis in interleukin-6-deficient mice. Infect Immun. 1997; 65(6): 2339-45.

PubMed Abstract | Publisher Full Text | Free Full Text

61. Drögemüller K, Helmuth $U$, Brunn A, et al:: Astrocyte gp130 expression is critica for the control of Toxoplasma encephalitis. J Immunol. 2008; 181(4): 2683-93. PubMed Abstract | Publisher Full Text

62. Sarkar S, Keswani T, Sengupta A, et al.: Differential modulation of glial cell mediated neuroinflammation in Plasmodium berghei ANKA infection by TGF $\beta$ and IL 6. Cytokine. 2017; 99: 249-59. PubMed Abstract | Publisher Full Text | Free Full Text

63. Jones LA, Roberts F, Nickdel MB, et al.: IL-33 receptor (T1/ST2) signalling is necessary to prevent the development of encephalitis in mice infected with
Toxoplasma gondii. Eur J Immunol. 2010; 40(2): 426-36.

PubMed Abstract | Publisher Full Text

64. S Still KM, Batista SJ, O'Brien CA, et al.: Astrocytes promote a protective immune response to brain Toxoplasma gondii infection via IL-33-ST2 signaling. PLoS Pathog. 2020; 16(10): e1009027.

PubMed Abstract | Publisher Full Text | Free Full Text

Faculty Opinions Recommendation

65. Vainchtein ID, Chin G, Cho FS, et al: Astrocyte-derived interleukin-33 promotes microglial synapse engulfment and neural circuit development. Science. 2018; 359(6381): 1269-73.

PubMed Abstract | Publisher Full Text | Free Full Text | Faculty Opinions Recommendation

66. Wang Y, Fu WY, Cheung K, et al:: Astrocyte-secreted IL-33 mediates homeostatic synaptic plasticity in the adult hippocampus. Proc Natl Acad Sci U S A. 2021; 118(1): e2020810118.

PubMed Abstract | Publisher Full Text | Free Full Text

67. Cekanaviciute E, Dietrich HK, Axtell RC, et al.: Astrocytic TGF- $\beta$ signaling limits inflammation and reduces neuronal damage during central nervous system Toxoplasma infection. J Immunol. 2014; 193(1): 139-49. PubMed Abstract | Publisher Full Text | Free Full Text

68. Shih RH, Wang CY, Yang CM: NF-kappaB Signaling Pathways in Neurological Inflammation: A Mini Review. Front Mol Neurosci. 2015; 8: 77. PubMed Abstract | Publisher Full Text | Free Full Text

69. Lian $\mathrm{H}$, Yang L, Cole A, et al.: NFKB-activated astroglial release of complement C3 compromises neuronal morphology and function associated with Alzheimer's disease. Neuron. 2015; 85(1): 101-15. PubMed Abstract | Publisher Full Text | Free Full Tex

70. Jin Y, Yao Y, El-Ashram S, et al.: The Neurotropic Parasite Toxoplasma gondii nduces Astrocyte Polarization Through NFкB Pathway. Front Med (Lausanne). 2019; 6: 267.

PubMed Abstract | Publisher Full Text | Free Full Text

71. Rameshwar P, Narayanan R, Qian J, et al:: NF-kappa B as a central mediator in the induction of TGF-beta in monocytes from patients with idiopathic myelofibrosis: an inflammatory response beyond the realm of homeostasis. $J$ Immunol. 2000; 165(4): 2271-7. PubMed Abstract | Publisher Full Text

72. Szu JI, Binder DK: The Role of Astrocytic Aquaporin-4 in Synaptic Plasticity and Learning and Memory. Front Integr Neurosci. 2016; 10: 8 . PubMed Abstract | Publisher Full Text | Free Full Text

73. Promeneur D, Lunde LK, Amiry-Moghaddam M, et al.: Protective role of brain water channel AQP4 in murine cerebral malaria. Proc Natl Acad Sci U S A. 2013, 110(3): 1035-40.

PubMed Abstract | Publisher Full Text | Free Full Text

74. DellaValle B, Hempel C, Kurtzhals JA, et al.: In vivo expression of neuroglobin in reactive astrocytes during neuropathology in murine models of traumatic brain injury, cerebral malaria, and autoimmune encephalitis. Glia. 2010; 58(10): 1220-7.

PubMed Abstract | Publisher Full Text

75. Liddelow SA, Guttenplan KA, Clarke LE, et al:: Neurotoxic reactive astrocytes are induced by activated microglia. Nature. 2017; 541(7638): 481-7. PubMed Abstract | Publisher Full Text | Free Full Text | Faculty Opinions Recommendation

76. Zamanian JL, Xu L, Foo LC, et al.: Genomic analysis of reactive astrogliosis.

J Neurosci. 2012; 32(18): 6391-410.

PubMed Abstract | Publisher Full Text | Free Full Text |

Faculty Opinions Recommendation 